\title{
Obozitoak in vitro heltzeko teknika (IVM): enbrioiaren garapen egokirako erronka
}

\author{
(Oocyte in vitro maturation (IVM): \\ the challenge for a good-quality embryo development)
}

\author{
Lide Totorikaguena Iturriaga*, Estibaliz Olabarrieta López, \\ Naiara Agirregoitia Marcos, Ekaitz Agirregoitia Marcos
}

Fisiologia Saila, Medikuntza eta Erizaintza Fakultatea Leioa (UPV/EHU)

\begin{abstract}
LABURPENA: Ugaztun emeen obozitoen heltze-prozesua ugalkortasunean garrantzi handia duen prozesua da, obulua ernaldua izateko ezinbestekoa delako. Gainera, heltze-prozesuak baldintzatzen du sortu behar den izaki berria, garapen-bidean dagoen enbrioiaren kalitatea zuzenean lotuta baitago obozitoaren heldutasunarekin eta kalitatearekin. Izan ere, obozitoen heltze-prozesuarekin erlazionatutako aldaketa nuklear eta zitoplasmatiko egokiak funtsezkoak dira obulazio eta haren ondorengo ernalketa zuzen baterako. Erronka nagusietariko bat da, beraz, heltze-prozesuan garrantzitsuak diren seinaleztapen-bidezidorrak eta elkarrekintza konplexuak zehaztea. Horrela, emakumezkoen ugal-fisiologia hobeto ulertzeaz gain, obozitoen in vitro heltze-prozesua modulatuz, lagunduriko ugalketa-teknikak optimizatzen lagundu genezakeelako: besteak beste, obozitoak in vitro heltzeko (IVM) teknika. Teknika horren bidez, pazienteari oraindik helduta ez dauden obozitoak erauzten zaizkio eta exogenoki heltzen dira hazkuntza-inguruneetan. Modu horretan, albo-kalte ugari eragiten dituen gonadotropinak hartzea saihesten da, eta hormonazioa kontraindikaturik daukaten emakumeentzat haurdun geratzeko aukera bakarrenetarikoa da. Teknika horren ezarpenak aurrerapen ugari dakartzan arren (esaterako, albo-kalte eta kostu ekonomiko gutxiago), oraindik gutxi erabiltzen da, beste ugal-tekniken arrakasta-mailara heldu ez delako.
\end{abstract}

HITZ GAKOAK: obozitoa, obozitoen heltze-prozesua, meiosiaren geldiaraztea, IVM teknika.

\begin{abstract}
Oocyte's maturation is a very important process in fertility because it is necessary for subsequent fertilization. In addition, maturation process influences the embryo, since the quality of the developing embryo is directly related to the maturity and the quality of the oocyte. This growth culminates just prior to ovulation during oocyte maturation. Adequate nuclear and cytoplasmic changes associated with maturation process of oocytes are fundamental for correct ovulation and subsequent fertilization. One of the main challenges is to determine the molecular pathways that regulate that maturation process. In addition, to better understanding female reproductive physiology, we could help to optimize the reproductive techniques by modulating the process of oocyte in vitro maturation, through the IVM technique. This technique consists in turning immature oocytes to mature exogenously in a culture media supplemented with different molecules to promote maturation. The most important advantage of IVM method is that could be the only hope or, at least, an alternative for a high number of patients unable to tolerate high doses of gonadotropins. Among the ARTs, the in vitro maturation oocytes (IVM) is less developed than other techniques, but its implementation would entail a qualitative advance.
\end{abstract}

KEYWORDS: oocyte, oocyte maturation, meiotic arrest, IVM.

\footnotetext{
* Harremanetan jartzeko / Corresponding author: Lide Totorikaguena Iturriaga. Fisiologia Saila, Medikuntza eta Erizaintza Fakultatea, Sarriena Auzoa (48940 Leioa). - lide.totorikaguena@ehu.eus - https://orcid.org/0000-0002-8315-4608.

Nola aipatu / How to cite: Totorikaguena Iturriaga, Lide; Olabarrieta López, Estibaliz; Agirregoitia Marcos, Naiara; Agirregoitia Marcos, Ekaitz (2021). "Obozitoak in vitro heltzeko teknika (IVM): enbrioiaren garapen egokirako erronka»; Ekaia, 39, 2021, 79-90. (https://doi.org/10.1387/ekaia.21880).
}

Jasoa: 2020, ekainak 30; Onartua: 2020, urriak 27

ISSN 0214-9001 - elSSN 2444-3255 / (c) 2021 UPV/EHU

cc)(1) Obra hau Creative Commons Atribución 4.0 Internacional-en lizentziapean dago 
Lide Totorikaguena Iturriaga, Estibaliz Olabarrieta López, Naiara Agirregoitia Marcos, Ekaitz Agirregoitia Marcos

\section{SARRERA}

Obozitoak in vitro heltzeko teknikan (IVM), obozito heldugabeak erauzi egiten dira in vitro heltzeko, eta, ondoren, ezagunagoa den in vitro ernalketa (IVF) teknika erabiltzen da. IVM oso aukera aproposa da, obozitoen eta enbroien kopurua emendatzeko erabiltzen den gonadotropinen bidezko obarioen estimulazioa gutxitzen edo saihesten delako. Azken hamarkadan, IVM teknikaren hobekuntza nabarmenak izan diren arren, IVMaren emaitzak ez dira beste ugalketa-teknikak bezain eraginkorrak, eta oso aldakorrak dira klinika batetik bestera (heltze-tasari, enbrioi-tasari eta IVM teknikatik eratorritako enbrioiak ezartzeko ahalmenari dagokienez): besteak beste, in vitro heltzean, obozitoaren garapen-gaitasun egokia eskuratzen ez delako, ernaldua izateko gaitasuna eta enbrioi bideragarri bihurtzeko gaitasuna, alegia [1]. Obozitoaren garapen-gaitasuna gradualki lortzen da folikulugenesian zehar, eta horregatik da garrantzitsua etapa horietan gertatzen dena ulertzea.

Obozitoa enbrioiaren hazkuntzaren oinarria da, hau da, bizitzaren oinarria, eta, hortaz, obozitoa oso zelula berezia eta ulertzen konplexua da. Obozitoaren hazkundea eta heltzea oso ondo koordinaturiko prozesuak dira, eta, akatsak izanez gero, epe luzeko ondorioak izan ditzake ugalkortasunean eta, ondorioz, ondorengoen osasunean. Izan ere, heltze-prozesuak baldintzatzen du sortu behar den izaki berria [2]. Garapen-bidean dagoen enbrioiaren kalitate egokia zuzenean lotuta dago obozitoaren heldutasunarekin eta kalitatearekin, eta heltze eta kalitate apalagoko obozitoak, aldiz, ernalketa-tasa baxuagoekin eta enbrioiaren ondorengo garapen txikiagoarekin. Beraz, kalitate oneko obozitoa ezinbesteko baldintza da enbrioia garatu eta bizirauteko [3]. Obozitoak enbrioiari osagai kromosomikoaren erdia ematen dio, baina bi gurasoen genomak ez dira simetrikoak, eta ez diote ekarpen bera egiten enbrioiari. Bere genoma nuklearraz gain, obozitoek mitokondrioak eta beste konposatu zitosolikoak ematen dituzte. Mitokondrioek beren DNA (mtDNA) dute, eta mtDNA ama-lerro germinaletik bakarrik transmititzen da [4].

Organismo baten ugalketa sexualaren lehen fasea gametogenesia da, obulutegietan eta testikuluetan dauden zelula germinaletatik gametoak eratzeko prozesua. Prozesu horri obogenesia deritzo emeetan eta espermatogenesia arretan, eta, meiosian zehar kromosoma bakoitzaren bikotekidea galtzen dutenez, zelula germinal haploideak (n) (obozitoak eta espermatozoideak) sortuko dira [5]. Gizakian, zelula germinalek 23 kromosoma dituzte, eta zelula somatikoek, aldiz, 46 kromosoma, hau da, diploideak dira (2n). Espermatogenesian zehar aldaketak gertatzen dira bolumenean, eduki zitoplasmatikoaren galeran eta kromatina nuklearraren berrantolaketan, eta espermatozoide helduek galdua dute proteinen adierazpena eta besikulen garraioa [6]. Horregatik, ekarpen bakarra genetikoa da (RNAi, RNA txi- 
kiak...), zeren eta hasierako enbroiaren garapenarena obozitoaren mRNAren eta folikulugenesian eta heltze-prozesuan metatutako proteinen araberakoa baita [7].

Hortaz, beharrezkoa da ernalketaren mekanismoak ulertzeko obozitoan gertatzen diren aldaketak zehatz-mehatz jakitea, jatorri enbrionariotik hasita ernaltzeko gai den zelula oso espezializatua bihurtzeraino: II. metafaseko estadioan dagoen obozitoraino, alegia. Izan ere, lehen aipatu dugun bezala, emeen ugalkortasun zuzena obozitoaren garapen egokiaren araberakoa da. Hazkuntza hori obulazioa baino lehenxeago hasten da, obozitoa heltzen denean. Obozitoaren heltze-prozesuan, meiosia berraktibatzen da, eta, horri esker, obozitoek aurrera egiten dute, I. profasetik meiosiaren II. metafasera [8].

\section{FOLIKULUGENESIA ETA OBOGENESIA}

\subsection{Folikulugenesia}

Obulutegia, gonada femeninoa, zelula germinalen (obozitoen) iturria da eta baita hormona sexual esteroideen hornitzaile nagusia ere [9]. Obulutegian obozitoen garapenerako oinarrizko egitura histo(fisio)logikoa folikulua da, eta obozitoez, pikor-geruzako zelulez eta teka zelulez osatuta dago. Erraz ulertzeko: folikulua izango litzateke obozitoaren etxea.

Folikulogenesian, folikulu primordialak hazi eta bereizi egiten dira obulazio aurreko folikuluraino (de Graaf-en folikulua izenez ere ezagutzen dena). Obozitoaren garapen-gaitasuna, hau da, obozitoak meiosia berraktibatzeko eta osatzeko, ernaltzeko eta enbrioi bideragarri bat sortzeko duen gaitasuna, modu naturalean lortzen da folikulogenesian zehar [10].

Eme ugaztun guztien obozitoak fetuaren garapenean zehar sortzen dira. Esan bezala, horietako milaka obulutegian ageri dira, eta folikulu primordialen barruan daude. Ugaztunetan, obozitoa pikor-geruzako zelula deituriko geruza bakarreko zelula aitzindariekin elkartzean hasten da folikulugenesia, folikulu primordialak sortzean eta, espeziearen arabera, jaio aurretik edo ostean gertatzen da [9]. Folikulugenesia prozesu jarraitua da, eta, sexualki heltzean (gizakietan pubertaroan), emakumearen obulazio-zikloaren fase folikularrean, erreklutamendu folikularraren fenomenoa hasten da. Hazten jarraitzen duenak garapen fase guztietatik pasatu beharko du: folikulu primordiala, primarioa, sekundarioa, aurreantrala, antrala, dominatzailea eta obulatzailea [11] (ikus 1. irudia). Gainerako folikuluek ez badute garapenarekin jarraitzen, endekatu egingo dira, hau da, atresia-egoeran sartuko dira. Prozesu horretan, folikulua garatu ez ezik, obozitoa hazi egiten da, pikor-geruzako zelulak eta teka-zelulak ugaritu egiten dira, antroa izeneko barrunbea agertzen da eta esteroidogenesia hasten da. Jakina da hau- 
tapen- eta nagusitasun-prozesu hori kontrol endokrinoaren bidez gertatzen dela, eta gonadotropina-mendekoa dela, nahiz eta ez den ezagutzen zein faktorek zehazten duten folikulu jakin baten erreklutamendua (folikulu dominatzailea), eta ez beste batena.

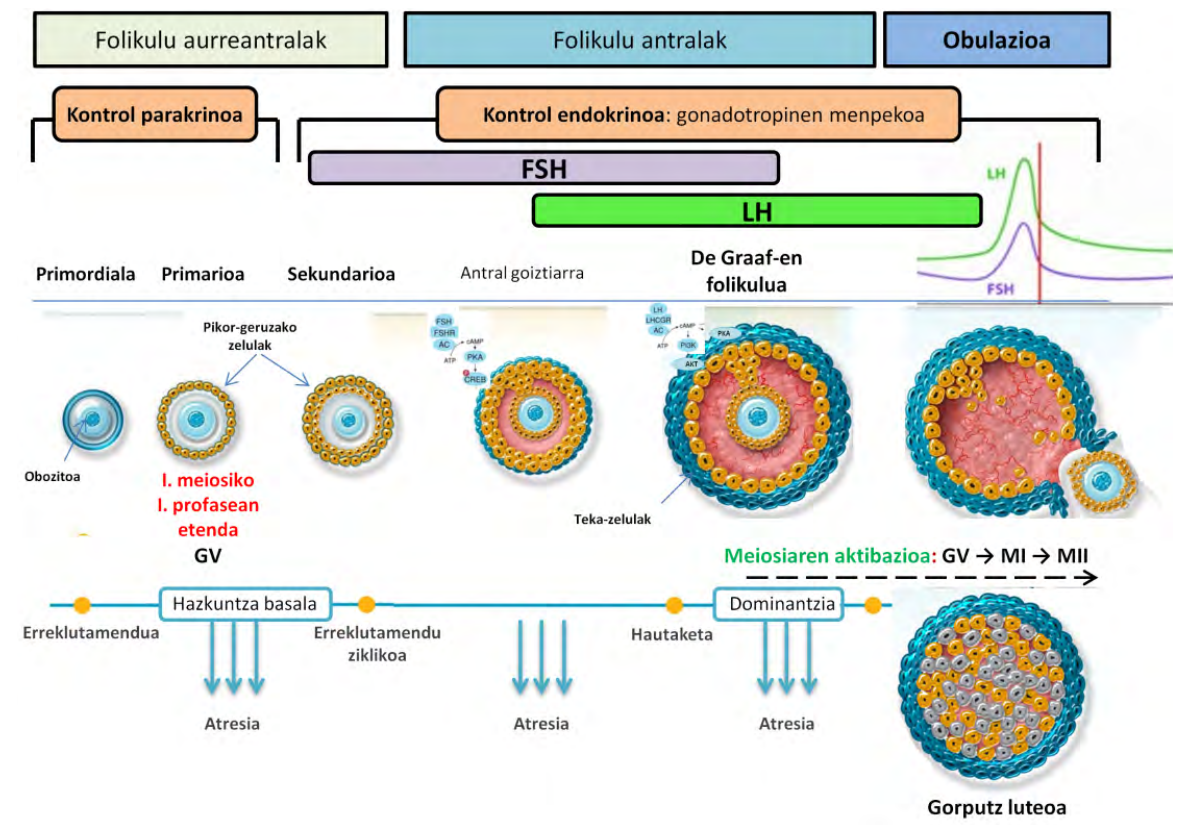

1. irudia. Folikulugenesiaren fase nagusien eskema. Folikulogenesia folikuluaren garapen-prozesua da, eta folikulua obozitoa inguratzen duen pikor-geruzako zelulez osatutako egitura da. Horren barruan gertatzen da obogenesia eta obozitoaren zatiketa meiotikoa (Besikula germinala $(\mathrm{GV})$, I. metafasea (MI) eta II. metafasea (MII)). Folikuluen hazkuntzaren lehenengo etapak folikulu sekundarioa eratu arte gonadotropinekiko independenteak dira. Hortik aurrera, hazkunde hormona folikulu-estimulatzailearen (FSH) araberakoa da. Azkenik, obulazioa gertatzen da hormona luteinizatzailearen (LH) estimulazio-tontorrari esker (Ansh Lab-etik moldatutako irudia [12]).

\subsection{Obogenesia}

Obozitoen sorrerari dagokionez, aurretiaz aipatu bezala, obozitoak folikuluetan sortzen dira. Lehen etxeari buruz ari ginen eta oraingoan, berriz, hango biztanleei buruz. Ugaztun emeetan, jaiotzean, folikulu primordialen barnean dauden obozitoak I. zatiketa meiotikoaren I. profaseko diplotenoan geldituta daude, zelula folikular lauez inguratuta. Obulutegian dauden obozito horiek enbrioiaren endodermotik eratortzen diren zelula germinal primordialetik sortzen dira. Ondoren, mesenteriorantz migratuko dute, eta 
gandor genitaletan kanporatzen dira. Hasieran, zelula germinal primordialak obulutegira garraiatuko dira transferentzia pasiboaren bidez, enbrioiaren garapenean zehar gertatzen diren aldaketengatik. Behin garatu gabeko obulutegira heltzean, zelula horiek mugikortasuna galtzen dute, eta obogonia ( $2 \mathrm{n}$ ) bihurtzen dira. Obogoniak zatiketa mitotikoaren ondorioz banatzen hasiko dira kopuruz handitu arte. Azken horiek meiosian sartuko dira, eta obozito primarioak sortuko dira, eta lehen zatiketa meiotikoko profasean sartuko dira.

\section{OBOZITOAREN HELTZE-PROZESUA}

Ugaztun emeen obozitoen heltze-prozesua ugalkortasunean garrantzi handia duen prozesua da, ezinbestekoa baita obulua ernaldua izateko [8].

Obozitoen heltze-prozesua obogenesiaren azken etapa da, guztiz garatua dagoen obozitoa (n) ernalketarako prestatzen den etapa. Heltze-prozesuan obozitoak zenbait aldaketa izaten ditu: batetik, heltze nuklearra edo besikula germinaletik (GV) II. metafasera bitarteko progresioa [13], eta, bestetik, zelula-organuluen aldaketa eta birbanaketarekin eta produktu geniko berrien ekoizpenarekin zitoplasmako heltzea [14].

Ugaztunetan, obozitoetan lehenengo aktibazio meiotikoa enbrioiaren garapenean zehar gertatzen da, eta, arestian aipatu bezala, jaiotzean I. profaseko diploteno fasean blokeatuta geratzen dira heldutasun sexuala lortu arte (gizakietan, nerabezaroan). Obozito heldugabe horiek besikula germinal izenez izendatzen dira (GV), besikula germinala ageri delako etapa horretan. Besikula germinala nukleoak jasotzen duen izena da, obozitoaren etapa horretan itxura urtsua eta tamaina handia duelako. Ugalketa-ziklo bakoitzean zehar, LHaren kontzentrazioaren gorakadak meiosiaren berraktibazioa eragiten du II. metafasera (MII) arte, hots, obozitoen heltze-prozesua bultzatzen du [15]. Ugaztunetan, obozitoek meiosia oraindik etapa fetalean daudenean hasten da, obulutegietan, baina heldutasun sexuala iristean eta ugalketa-aparatuan ernaldu ondoren bakarrik amaitzen dute. Izan ere, espermatozoide bat ernaldu ahal izateko, obozitoak II. metafasean egon behar du eta, ernalketa gertatzen baldin bada, bukatuko da meiosia, zigotoaren zatiketa mitotikoarekin enbrioiaren garapena abiatzeko [16].

Obozitoaren heltze-prozesuan zehar zitoplasman, mintzean eta nukleoan aldaketa ugari gertatzen dira, obozitoa ernalketarako ondo prestatuta egon dadin eta enbrioia garapenaren lehenengo etapan mantendu ahal izateko. Heltze nuklearraren kasuan, aldaketa nagusien artean daude, besteak beste, besikula germinalaren (GV) haustura (GVBD), kromosomen kondentsazioa eta I. metafasera arte (MI) aurreratzea, lehenengo korpuskulu polarraren estrusioa eta bigarren zatiketa meiotikoaren metafasean (MII) gelditzea [14] (ikus 2.irudia). Azpimarratu behar da meiosia zelula 
Lide Totorikaguena Iturriaga, Estibaliz Olabarrieta López, Naiara Agirregoitia Marcos, Ekaitz Agirregoitia Marcos

germinalen (espermatogonia eta obogonia) bereizgarria den zelula-zatiketa mota dela. Haren helburua bikoitza da: kromosoma kopuru diploide (2n) bat kopuru haploide (n) batera murriztea eta informazio genetikoaren birkonbinazioa egitea [17].
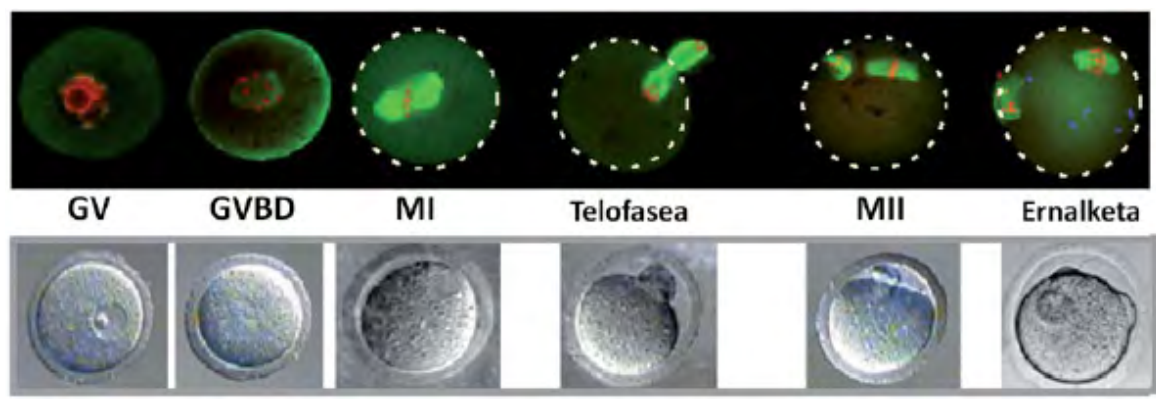

2. irudia. Heltze-prozesua: nukleoaren heltzearen aldaketa-fase nagusiak. Goian, obozitoen inmunofluoreszentzia heltze-prozesuan [mikrotubuluak (berdez), kromatina (gorriz) eta espermatozoideak (urdinez)]. Behean, obozitoen morfologia heltze-prozesuan. Laburdurak: GV: besikula germinala; GVBD: besikula germinalaren haustura; MI: I. Metafasea; MII: II. Metafasea [18].

Adinarekin eta hilekoaren ziklo (gizakietan) edota ziklo estral (gainerako ugaztun gehienetan) bakoitzaren agerpenarekin, folikuluen erreserba kantitatea eta kalitatea gutxituz doa, ugaztunen ugal-adina zehaztuz [19]. Esaterako, gizakietan, 500 obozito baino gutxiago obulatzen dira ugal-bizitzan zehar, baina jaiotzerakoan 300.000-400.000 obozito inguru daude [20]. Beraz, oro har, 1.600 folikulu primarioetatik bakarrak bukatuko du hilero heltze-prozesua, eta obulaziora iritsiko da.

\section{MEIOSIAREN GELDIARAZTEA ETA BERRAKTIBAZIOA}

Meiosiaren geldiaraztea edota berraktibazioaren inguruan, gaur-gaurkoz, zalantza ugari daude, baina gero eta indar handiagoa hartzen ari da cAMPek duen paper garrantzitsua. Badirudi folikuluen oboplasmako AMP ziklikoaren (cAMP) mailaren erregulazioak baldintzatzen duela: cAMPen maila altuek meiosia inhibitzen dute, eta cAMPren maila baxuek, aldiz, berraktibatu [21]. Esan bezala, oraindik ez dira guztiz ezagutzen zein diren cAMPen mailak erregulatzen dituzten mekanismoak, baina obozitoaren barruan cAMP mailak erregulatzeko prozesuen hipotesi ezberdinak plazaratu dira:

- cAMParen sarrera obozitoaren eta pikor-geruzako zelulen arteko Gap loturen bidez gertatzea [22]. 
- Obozitoaren cAMParen sintesi endogenoa $G$ proteinari lorturiko hartzaile baten bidez gertatzea [23].

a) Adenilato ziklasaren bidez, ATP cAMP bihurtzen da [24].

b) Proteina kinasa A-ren (PKA) aktibazioaren bidez heltze-prozesua sustatzeko faktorea (Maturation Promoting Factor ingelesez, MPF) inaktibatzen da.

- Zelula somatikoek (teka zelulak eta pikor-geruzako zelulek) Guanosina Monofosfato ziklikoz (cGMP) hornitzea obozitoa. cGMPek fosfodiesterasaren (PDE) jarduera inhibitzen du (cAMP degradatzen duen entzima) [25].

Dena den, oraindik ezezagunak diren arren obozitoeen heltze-prozesua pizten duten seinaleak, gero eta ziurtasun handiagoa dago seinale horietako asko $\mathrm{G}$ proteinei loturiko hartzaileen (GPCR) menpe daudela, eta GPCR hartzaile horien aktibazioak edo inaktibazioak obozitoen heltzeprozesua modulatzen dituzten seinalizazio ur-jauziak pizten dituztela [25]. Beraz, berpizkunde meiotikoa eragiten eta erregulatzen duten kanpo-seinaleak aurkitzen badira, baliteke farmakoen bidez heltze-prozesua kontrolatzea $[26,27,28,29,30]$.

\section{OBOZITOA IN VITRO HELTZEKO TEKNIKA (IVM)}

IVM teknika lehenengo aldiz 1934. urtean proposatu zuten Pincus eta Enzemann-ek [31], baina 1990eko hamarkada hasierara arte ez zen lehenengo haurra jaio [32]. IVM teknika agertzeak obozitoen heltzearekin erlazionatutako fenomenoen oinarrizko ezagutza handitzeaz gain, in vitro ernalketa-teknikak optimizatzeko saiakeran aurrera egiten lagundu du.

IVM teknikan, pazienteari, hormonekin estimulatu gabeko obarioetatik edo estimulazio txikia jaso duten obarioetatik, heldu gabeko obozitoak erauzten zaizkio eta hazkuntza-inguruneetan heltzen dira, ondoren bestelako ugalketa-tekniken bidez haurdunaldia lortzen saiatzeko [33] (ikus 3. irudia).

In vitro heltze-teknikei esker, obulutegien estimulazioa gomendatzen ez zaien emakumeek haurdunaldia lor dezakete hormona-tratamendurik gabe. Aukera hori, batez ere, obulutegi polikistikoak dituzten emakumeetan erabili izan da, obulutegien hiperestimulazioa saihesteko [34]. Izan ere, hormonak hartzeak albo-kalte ugari dakartza, baina ez soilik obulutegi polikistikodunentzat: besteak beste, emakumeen \% 10ek hormonei txarto erantzuten die, IVF zikloen \% 33ek obarioen hiperestimulazio-sindromea izateko arriskua dauka eta, \% 33 horietatik, kasu larrienetan hil egiten dira [35]. Beste zenbait emakumerentzat ere ez da gomendagarria hor- 
Lide Totorikaguena Iturriaga, Estibaliz Olabarrieta López, Naiara Agirregoitia Marcos, Ekaitz Agirregoitia Marcos

monen bidezko tratamendua: adibidez, obulutegi polikistikodun sindromea daukatenentzat eta minbiziaren aurkako tratamenduak jaso dituzten pazienteentzat [36]. Gainera, azken urteotan familia-ereduetan izan den bilakaerarengatik (bikote homosexualak edota gurasobakarrak), gero eta gehiago dira IVM teknikaren onuraz balia litezkeenak, antzutasun-arazorik ez izanda teknika hori delako hormonak hartzea saihesteko teknikarik aproposena lagunduriko ugal-prozesua aurrera eramateko.

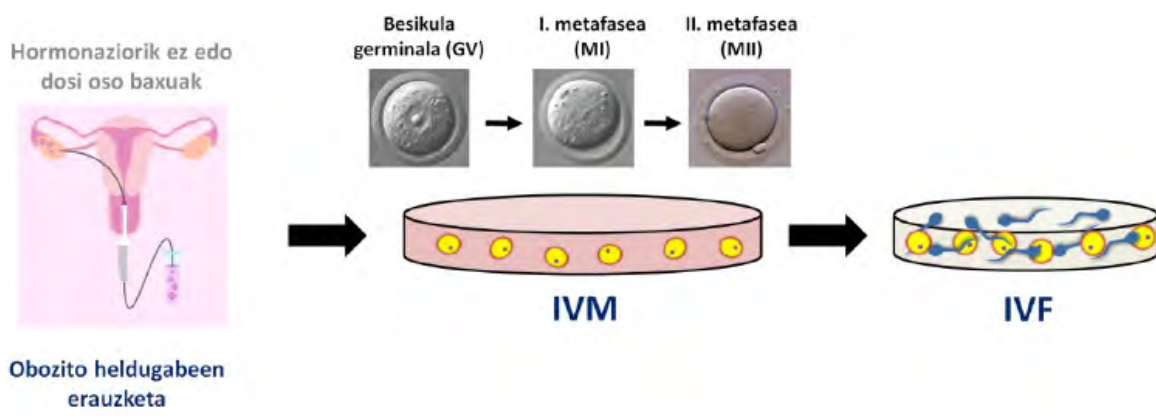

3. irudia. Obozitoak in vitro heltzeko teknika (IVM). Hormona-dosi gabe edo dosi baxuarekin estimulaturiko obulutegietatik obozito heldugabeak erauzten dira, ondoren, laborategian IVM teknikaren bidez petri kutxetan obozitoak exogenoki heltzeko ingurune berezietan. Behin obozitoak helduta, in vitro ernaltzen dira in vitro ernalketa (IVF) edo espermatozoide-injekzio intrazitoplasmatikoa (ICSI) tekniken bidez haurdunaldia lortzen saiatzeko.

Hala ere, nahiz eta azken hamarkadan IVM teknikaren hobekuntza nabarmenak izan diren, IVMaren emaitzak ez dira beste ugalketa-teknikak bezain eraginkorrak eta hau da gutxien garatuta dagoena (urtean, kliniketan egiten diren ugal-ziklo induzitu guztien \% 0,1) [37].

\section{ONDORIOAK}

Nabarmendu behar da meiosiaren geldiaraztearen mantentze-prozesuak seinaleztapen zelular konplexu bat eskatzen duela, obulazio aurreko FSHaren eta LHaren estimuluen bidez eraldatzen dena, eta, horren ondorioz, meiosia berraktibatzen da eta obozitoa heltzen da. Gertaera parakrinoak ere badira, folikulu-zelulen eta obozitoaren arteko barne-harremanen arabera gertatzen direnak. Gertaera horiek guztiak beharrezkoak dira ernalketaren ondorengo enbrioi osasuntsu batean garatzeko ahalmena duen gameto funtzionala ekoizteko; gero eta ebidentzia gehiago baitago obozitoaren kalitateak zeharo eragiten duela ondorengo ernalketan eta enbrioien garapen egokian. 
Horrez gain, obozitoen heltze-prozesua ezagutzea funtsezkoa da in vitro enbrioien produkzioaren arrakasta handitzeko eta antzutasunaren aurkako tratamenduak garatzeko. Gaur-gaurkoz, IVM teknika metodo erabilienetariko bat da abeltzaintzan, zelula-ama enbrionarioen teknologietan, klonazioan eta animalia transgenikoen ekoizpenean [38]; baina, aldiz, gizakietara bideratutako tratamenduetan ez da horren erabilia, nahiz eta IVM metodoaren abantaila garrantzitsuena den hormonen estimulazioen ondorioz gerta litezkeen albo-kalteak murriztuko liratekeela eta haurdunaldia lortzeko aukera bakarra izan daitekeela beste zenbait pazienterentzat. Beraz, IVM teknikak etorkizun oparoa izan dezake lagunduriko ugalketaren esparruan, baldin eta obozitoaren heltze-prozesuko osagai garrantzitsuenak ezagutzen baditugu eta gai bagara in vitro tratamendu egokiak bideratzeko. Emakume askoren bizi-kalitatea hobetzeaz gain, nabarmen murriztuko lituzke kostua, arriskua eta karga psikologikoa. Halaber, lagunduriko ugalkortasun-teknika ohikoak horren hedatuak ez dauden munduko beste hainbat herrialdetara irekiko luke IVM bidezko tratamendua egiteko aukera. Horra hor dugun erronka.

\section{BIBLIOGRAFIA}

[1] SANCHEZ, F., LOLICATO, F., ROMERO, S., DE VOS, M., VAN RANST, H., VERHEYEN, G., ANCKAERT, E. eta SMITZ, J.E.J. 2017. «An improved IVM method for cumulus-oocyte complexes from small follicles in polycystic ovary syndrome patients enhances oocyte competence and embryo yield». Hum Reprod. 32(10), 2056-2068

[2] KRISHER RL. 2013. Oocyte physiology and development in domestic animals. Wiley-Blackwell.

[3] VARGhese, A.C., LY, K.D., CORBin, C., MENDiOlA, J. eta AGARWAL, A. 2011. «Oocyte developmental competence and embryo development: impact of lifestyle and environmental risk factors».Reprod Biomed Online. 22, 410-20

[4] KEEFE, D., KUMAR, M. eta KALMBACH, K. 2015. «Oocyte competency is the key to embryo potential». Fertility and Sterility. 103(2), 317-22. Review.

[5] RAHMAN, A. N. M. A., ABDULLAH, R. B. eta WAN-KHADIJAH, W. E. 2008. «Gametogenesis, Fertilization and Early Embryogenesis in Mammals with Special Reference to Goat: A Review». Journal of Biological Sciences. 8 (7), 1115-1128.

[6] MILLER, D. eta OSTERMEIER, G. C. 2006. «Towards a better understanding of RNA carriage by ejaculate spermatozoa». Human Reproduction. 12(6):757-767.

[7] HARDY, K. 2002 «The oocyte as a machine. Assisted reproductive technology. Acomplishments and new horizons». Cambridge University Press, Cambridge. 70-80. 
Lide Totorikaguena Iturriaga, Estibaliz Olabarrieta López, Naiara Agirregoitia Marcos, Ekaitz Agirregoitia Marcos

[8] JAMNONGJIT, M. eta HAMMES, S.R. 2005. «Oocyte maturation: the coming of age of a germ cell». Semin Reprod Med. 23(3), 234-41.

[9] MCGEE, E.A. eta HSUEH, A.J. 2000. «Initial and cyclic recruitment of ovarian follicles». Endocr Rev. 21, 200-14.

[10] VAN DEN HURK, R. eta ZHAO, J. 2005. «Formation of mammalian oocytes and their growth, differentiation and maturation within ovarian follicles». Theriogenology. 63, 1717-51.

[11] FAIR, T. 2003. «Follicular oocyte growth and acquisition of developmental competence». Anim Reprod Sci.78, 203-216.

[12] https://www.anshlabs.com/folliculogenesis/

[13] SIRARD, M.A. 2001. «Resumption of meiosis: mechanism involved in the meiotic progression and its relation with developmental competence». Theriogenology. 55, 1241-54.

[14] PICTON, H., BRIGGS, D. eta GOSDEN, R. 1998. «The molecular basis of oocyte growth and development». Mol Cell Endocrinol. 145, 27-37

[15] LIU, L., KONG, N., XIA, G. eta ZHANG, M. 2012. «Molecular control of oocyte meiotic arrest and resumption». Reprod Fertil Dev. 25, 463-71. doi: 10.1071/RD12310.

[16] SUN, Q.Y. eta NAGAI, T. 2003. «Molecular mechanisms underlying pig oocyte maturation and fertilization». Journal of Reproduction and Development. 49, 347-359.

[17] POLANSKI Z, HOFFMANN S eta TSURUMI C. 2005. «Oocyte nucleus controls progression through meiotic maturation». Dev Biol. 281, 184-95.

[18] KUBIAK, J.Z., CIEMERYCH, M.A., HUPALOWSKA, A., SIKORA-POLACZEK, M. eta POLANSKI, Z. 2008. «On the transition from the meiotic to mitotic cell cycle during early mouse development». Int J Dev Biol.52, 201-17.

[19] BROEKMANS, F.J., KNAUFF, E.A., TE VELDE, E.R., MACKLON, N.S. eta FAUSER, B.C. 2007. «Female reproductive ageing: current knowledge and future trends». Trends in Endocrinology \& Metabolism. 18, 58-65.

[20] HANSEN, K.R., KNOWLTON, N.S., THYER, A.C., CHARLESTON, J.S., SOULES, M.R. eta KLEIN, N.A. 2008. «A new model of reproductive aging: the decline in ovarian non-growing follicle number from birth to menopause». Hum Reprod. 23, 699-708.

[21] VANHOUTTE, L., NOGUEIRA, D., GERRIS, J., DHONT, M. eta DE SUTTER, P. 2008. «Effect of temporary nuclear arrest by phosphodiesterase 3 -inhibitor on morphological and functional aspects of in vitro matured mouse oocytes». Molecular reproduction and development. 75, 1021-30.

[22] VACCARI, S., HORNER, K., MELHMAN, L.M. eta CONTI, M. 2008. «Generation of mouse oocytes defective in cAMP synthesis and degradation:endogenous cyclic AMP is essential for meiotic arrest». Dev. Biol.316, 124-34.

[23] KALINOWSKI, R.R., BERLOT, C.H., JONES, T.L., ROSS, L.F., JAFFE, L.A. eta MEHLMANN, L.M. 2004. «Maintenance of meiotic prophase 
arrest in vertebrate oocytes by a G s protein-mediated pathway». Dev Biol. 267, 1-13.

[24] TORNELL, J., BILLING, H. eta HILLENSJO, T. 1991. «Regulation of oocyte maturation by changes in ovarian levels of cyclic nucleotides». Hum reproduction. 6, 411-22.

[25] SCHINDLER, K. 2011. «Protein kinases and protein phosphatases that regulate meiotic maturation in mouse oocytes». Results Probl Cell Differ. 53, 309-341.

[26] LOPEZ-CARDONA, A.P., SANCHEZ-CALABUIG, M.J., BELTRANBRENA, P., AGIRREGOITIA, N., RIZOS, D., AGIRREGOITIA, E. eta GUTIERREZ-ADAN, A. 2016. «Exocannabinoids effect on in vitro bovine oocyte maturation via activation of AKT and ERK1/2». Reproduction. 152, 603-612.

[27] LOPEZ-CARDONA, A.P., PEREZ-CEREZALES, S., FERNANDEZ-GONZALEZ, R., LAGUNA-BARRAZA, R., PERICUESTA, E., AGIRREGOITIA, N., GUTIERREZ-ADAN, A. eta AGIRREGOITIA, E. 2017. «CB1cannabinoid receptor drives oocyte maturation and embryo development via PI3K/Akt and MAPK pathways». FASEB J. 31, 3372-3382.

[28] OLABARRIETA, E., TOTORIKAGUENA, L., ROMERO-AGUIRREGOMEZCORTA, J., AGIRREGOITIA, N. eta AGIRREGOITIA, E. 2019. «Mu opioid receptor expression and localisation in murine spermatozoa and its role in fertilisation in vitro». Reproduction, Fertility and Development. doi: 10.1071/RD19176.

[29] TOTORIKAGUENA, L., OLABARRIETA, E., LÓPEZ-CARDONA, A.P., AGIRREGOITIA, N. eta AGIRREGOITIA, E. 2019. «Tetrahydrocannabinol modulates in vitro maturation of oocytes and improves the blastocyst rates after in vitro fertilization». Cellular Physiology and Biochemistry. 53, 439-52.

[30] TOTORIKAGUENA, L., OLABARRIETA, E., LOLICATO, F., ROMERO AGUIRREGOMEZCORTA, J., SMITZ, J., AGIRREGOITIA, N. eta AGIRREGOITIA, E. 2020. «The endocannabinoid system modulates the ovarian physiology and its activation can improve in vitro oocyte maturation». Journal of Cellular Physiology. doi: 10.1002/jcp.29663

[31] PINCUS, G. eta ENZMANN, E.V. 1934. «Can Mammalian Eggs Undergo Normal Development in Vitro?». Proc Natl Acad Sci U S A. 20, 121-2.

[32] CHA, K.Y., KOO, J.J., KO, J.J., CHOI, D.H., HAN, S.Y. eta YOON, T.K. 1991. «Pregnancy after in vitro fertilization of human follicular oocytes collected from nonstimulated cycles, their culture in vitro and their transfer in a donor oocyte program». Fertility and Sterility. 55, 109-13.

[33] DE VOS, M., SMITZ, J., THOMPSON, J.G. eta GILCHRIST, R.B. 2016. «The definition of IVM is clear-variations need defining». Hum Reprod. 31(11), 2411-2415.

[34] TROUNSON, A., WOOD, C. eta KAUSCHE, A. 1994. «In vitro maturation and the fertilization and developmental competence of oocytes recovered 
from untreated polycystic ovarian patients». Fertility and Sterility. 62, 353362. doi.org/10.1016/S0015-0282(16)56891-5

[35] HALUPCZOK, J., KLUBA-SZYSZKA, A., BIDZIŃSKA-SPEICHERT, B. eta KNYCHALSKI, B. 2015 «Ovarian Hyperstimulation Caused by Gonadotroph Pituitary Adenoma-Review». Advances in clinical and experimental medicine: official organ Wroclaw Medical University. 24, 695-703.

[36] NIKSERESHT, M., TOORI, M.A., RASTI, T., KASHANI, I.R. eta MAHMOUDI, R. 2015 «The Nuclear Maturation and Embryo Development of Mice Germinal Vesicle Oocytes with and without Cumulus Cell after Vitrification». J Clin Diagn Res. 9, AF01-04.

[37] KUPKA, M., D’HOOGHE, T., FERRARETTI, A., DE MOUZON, J., ERB, K., CASTILlA, J., CALHAZ-JORGE, C., DE GEYTER, C., GOOSSENS, V. eta CONSORTIUM, EI.M. 2016. «Assisted reproductive technology in Europe, 2011: results generated from European registers by ESHRE». Hum Reprod. 31, 233-248.

[38] HERTA, A.C., LOLICATO, F. eta SMITZ, J.E.J. 2018. «In vitro follicle culture in the context of IVF». Reproduction. 156, F59-F73. doi: 10.1530/ REP-18-0173. 